\title{
High load of hepatitis E viral RNA in pork livers but absence in pork muscle at French slaughterhouses
}

\author{
Feurer C. ${ }^{1,}$, Le Roux A. ${ }^{1}$, Rossel R. ${ }^{2}$, Barnaud E. ${ }^{3}$, Dumarest M. ${ }^{3}$, Garry Pascal ${ }^{4}$, Pavio N. ${ }^{3}$
}

${ }^{1}$ IFIP, French Institute for the Pig and Pork Industry, La Motte au Vicomte, B.P. 35104, 35651 Le Rheu, Cedex, France

${ }^{2}$ Arepsa, Route de Samadet, 64410 Arzacq, France

${ }^{3}$ UMR 1161 Virology, Anses Animal Health Laboratory, INRA, Ecole Nationale Vétérinaire d'Alfort, 14 rue Pierre et Marie Curie, 94701 Maisons-Alfort, France

${ }^{4}$ IFIP, French Institute for the Pig and Pork Industry, 7 avenue du Général de Gaulle, 94704 Maisons-

Alfort Cedex, France

*Corresponding author : C. Feurer, email address : carole.feurer@ifip.asso.fr

\begin{abstract}
:
Pork ham muscle can be contaminated with HEV via blood vessels during viremia and represents a possible source of human contamination via the consumption of dried ham. This study evaluated the prevalence of HEV RNA in pork ham muscles and pork livers at slaughterhouses. Serology was determined on the corresponding serum samples. The apparent individual seroprevalence rate in the 49 pig farms studied was $59 \%$ [55.5\%-61.4\%]. None of the 1134 ham muscles tested was positive for the presence of HEV. HEV prevalence in paired liver samples was $2.8 \%$ with a level of contamination of up to $1.46108 \mathrm{copies} / \mathrm{g}$. Sequences of viral strains isolated from positive livers belonged to genotype 3 and subtypes $3 \mathrm{c}, 3 \mathrm{e}, 3 \mathrm{f}$ and $3 \mathrm{j}$. Our results confirmed that raw pork liver food products are a source of risk for humans but they also showed that there is a limited risk of human infection by HEV through the consumption of ham muscle.
\end{abstract}

Highlights

Presence of Hepatitis E viral RNA in pork ham muscles and paired livers was evaluated. HEV was detected in $2,8 \%$ of the 1034 livers. None of the 1034 paired ham muscles was positive for the presence of HEV. The study showed a limited risk of contamination of ham muscles by HEV.

Keywords : Pork muscles, Hepatitis E virus, Food safety

\author{
Abbreviation : \\ HEV hepatitis E virus
}




\section{Introduction}

Hepatitis E virus (HEV) is responsible for acute entero-transmissible hepatitis in humans.

Most HEV infections evolve favorably except in pregnant women who have a case fatality rate that can reach $20 \%$ with HEV genotype 1 in some endemic regions (tropical and subtropical areas) (Navaneethan et al., 2008; Purcell and Emerson, 2008). In France and more generally in Europe, the USA and Japan, infections are predominantly autochthonous and caused by genotype 3 (HEV-3) or 4 (HEV-4), in contrast to endemic regions (Asia, Africa), where genotypes 1 (HEV-1) and 2 (HEV-2) prevail (Adlhoch et al., 2016). In France, HEV is not a notifiable disease but the national reference center records single and grouped cases of viral hepatitis E. In France in 2014, 1825 cases of hepatitis E were reported among which, 1813 were autochthonous (Adlhoch et al., 2016). Suspected for many years, it is now well established that HEV is also a zoonotic agent in industrialized countries with Suidae being the major animal reservoir of HEV-3 or HEV-4. Several reports describe human cases of Hepatitis E associated with foodborne transmission involving food products such as wild boar meat or offal and products containing undercooked raw pork liver (Li et al., 2005; Renou et al., 2014; Riveiro-Barciela et al., 2015). Pigs are asymptomatic carriers and become infected between 8 and 10 weeks of age after losing maternal immunity. The peak in fecal viral excretion is observed between 12 and 18 weeks of age (Pavio et al., 2010) and decreases gradually towards slaughter age (De Deus et al., 2008). Data available worldwide has confirmed a high level of HEV in pig herds (Pavio et al., 2010). Prevalence in pig herds ranged from $46 \%$ in Laos (Blacksell et al., 2007) to more than $98 \%$ in Spain, the USA or Mexico (Cooper et al., 2005; Jimenez et al., 2011; Meng et al., 1997; Seminati et al., 2008). A French survey conducted in 2009 estimated that $65 \%$ of pig farms investigated harbored infected animals and that $4 \%$ of pork livers entering the food chain were contaminated with HEV. The HEV viral load of pork livers was not determined (Rose et al., 2011). In 
comparison, HEV was detected in $1.3 \%, 1.9 \%, 11 \%$ and $6.5 \%$ of pig livers sold in retail stores in England, Japan, the USA and The Netherlands respectively (Bouwknegt et al., 2007; Feagins et al., 2007; Yasaki et al., 2003). Available data regarding the viral load in livers ranged from 65 copies of HEV genome/g in The Netherlands (Bouwknegt et al., 2007) to $10^{7}$ copies of HEV genome/g in Japan (Yasaki et al., 2003). Bouwknegt et al. (2009) showed after experimental infection, that biceps femoris, iliopsoas and longissimus could constitute possible sources of HEV transmission from pigs to humans. Di Bartolo et al. (2012) also showed that lingual muscles could be contaminated at the slaughterhouse. In contrast, in the UK in 2012, none of the 40 ventral abdomen muscles sampled at a processing plant by Berto et al. (2012) were HEV positive, nor were the 43 pork loins or 599 pork chops sampled in Canada at slaughter and retail (Leblanc et al., 2010; Wilhelm et al., 2015). Overall, data regarding the prevalence of HEV in muscles and the associated viral load are either scarce or lacking. The infectious oral dose for humans is estimated to be $10^{5.5} \mathrm{HEV}$ RNA copies/g (French Agency for food, environmental and occupational health and safety (Anses) 2009), thus it is important to determine the level of contamination of pork meat. Ham muscles and in particular gluteus medius or semi-membranosus can be a source of risk as they are highly irrigated and likely to be contaminated by HEV through blood vessels or arteries. Therefore, the objective of this study was to evaluate the prevalence of HEV in ham muscles at the time of slaughter in order to evaluate if there is a risk of human contamination through consumption of dried pork meat. We also investigated the viral load of infected liver and whether there was a link with possible muscle contamination. 1034 paired samples of muscle and liver were analyzed for detection and quantification of HEV RNA. Serology was determined on corresponding serum samples to confirm HEV farm exposure of tested animals. Genotypes of positive HEV samples were characterized by phylogenetic analysis. 


\section{Materials and methods}

\subsection{Sampling plan}

Considering a HEV prevalence in pork liver around 3 to $4 \%$ (Rose et al., 2011), we assumed that $0.3-0.4 \%$ of ham muscle could potentially be HEV positive. Using EpiTools we calculated that the sample size should be of 1109 (95\% confidence interval) in order to detect this prevalence level (Sergeant, 2017). Thus, from August to October 2011, 49 herds of growing-finishing pigs were randomly selected in regions of France where $81 \%$ of French pigs were reared in 2011 (IFIP, 2013). Per herd, 19 to 25 triplet samples of muscle, liver and blood were collected on the slaughter line. Sampling was performed by both the Ifip and the Arepsa.

\subsection{Sampling methods}

A $5 \mathrm{~mL}$ blood sample as well as $5 \mathrm{~g}$ of liver and $5 \mathrm{~g}$ of ham muscle were collected aseptically, frozen, sent to Anses $\left(-20^{\circ} \mathrm{C}\right)$ and stored at $-80^{\circ} \mathrm{C}$ until analysis. A total of 1034 triplet samples of blood, liver and muscle were collected. The 1034 individual blood samples were collected at the bleeding stage. The corresponding pork livers were collected either before veterinary inspection when offal was removed or after inspection. The ham samples were collected at the end of the slaughter line before chilling. The muscles collected were either gluteus medius or semi-membranosus.

\subsection{Molecular detection of HEV}

RNA extraction from muscle was performed manually using the QIAamp Viral RNA extraction Mini kit (QIAGEN, Illkirch, France) on muscle juice, according to the manufacturer's instructions except that $200 \mu \mathrm{L}$ of sample was used. Muscle juices were recovered after one cycle of freeze and thaw at $-20^{\circ} \mathrm{C}$. The $\mathrm{HEV}$ recovery from muscle 
juice and muscle homogenate (Fast-prep 24, MP Biomedicals, Illkirch, France) after spiking with a viral suspension of HEV3 (GenBank accession number EF494700), were compared and showed similar results. RNA extraction from liver was performed manually as described (Rose et al., 2011). HEV RNA detection in muscles and liver samples was performed using real-time quantitative RT-PCR as described previously (Barnaud et al., 2012). The limits of detection (LOD) were estimated to be 6600 genome copies/gram of liver and 1000 genome copies/ml of muscle juice. Thus, negative samples could potentially be below these LOD.

\subsection{Serological detection of $\mathrm{HEV}$}

The detection of anti-HEV antibodies was performed using the HEV ELISA 4.0v kit (MP Diagnostics, Illkirch, France) according to the manufacturer's instructions, except for the quantity of serum used, $10 \mu \mathrm{L}$ instead of $20 \mu \mathrm{L}$. This sandwich ELISA allowed the detection of all antibody classes ( $\operatorname{IgG}, \operatorname{IgM}$ and $\operatorname{Ig} \mathrm{A})$ and used a recombinant antigen that is present in all HEV strains. Samples were positive when the optical density at $450 \mathrm{~nm}$ wavelength obtained for the sample was higher than the threshold defined as the mean for negative controls +0.3 .

\subsection{Phylogenetic analysis}

Partial sequences of HEV ORF-2 capsid (Genbank accession numbers MF065990MF066010) were obtained after RT-nested PCR according to Rose et al. (2011) and compared to sequences available in Genbank. This genomic region is frequently used in phylogeny and reflects the diversity of HEV (Lu et al., 2006). After alignment with reference sequences for subtyping (Smith et al., 2016) and their closest sequences (Blast 5 
best hits), a phylogenetic tree was constructed after alignment with Muscle using MEGA software (MEGA6, www.megasoftware.net).

\section{Results and discussion}

\subsection{HEV seroprevalence}

The presence of antibodies against HEV was determined individually on 1034 serum samples. The apparent individual seroprevalence rate was of 60\% [57.8\%-63.7\%] (Table 1). Previous results obtained in France indicated a lower individual prevalence of $30 \%$ (Rose et al., 2011). This high seroprevalence could correspond to herds where HEV is enzootic, suggesting early infection of animals. Hepatitis E virus is highly prevalent among the domestic pig population in Europe. The individual seroprevalence in pigs over 6 months of age varied from study to study: 96\% (95/99) (Costanzo et al., 2015) in Italy, $92.8 \%(584 / 629)$ in the UK (Grierson et al., 2015), 49\% (97/200) in Switzerland (Wacheck et al., 2012), 61.6\% (234/380) in Estonia (Ivanova et al., 2015) and 68.6\% in Germany (354/516) (Wacheck et al., 2012b). In their review, Pavio et al., (2010) concluded that older pigs were usually associated with a higher seroprevalence rates. Our results are therefore consistent with these findings.

\subsection{HEV prevalence and quantification in pork livers}

The presence of HEV RNA was determined individually in 1034 livers. The apparent prevalence rate was of $2.8 \%$ [1.9\%-3.9\%] (Table 1). These results are consistent with results previously obtained in France (Rose et al., 2011). In Europe, similar prevalence rates have been reported: $6.5 \%$ in The Netherlands (Bouwknegt et al., 2007), 3\% in the UK (Berto et al., 2012), 5\% in the Czech Republic (Di Bartolo et al., 2012) and 4\% in Germany (Wenzel et al., 2011). The viral load found in the 29 positive liver samples 
ranged from $7.810^{3}$ copies/g to $1.4610^{8}$ copies/g with a median value of $1.310^{5}$ copies/g (Figure 1). Since the human oral infectious dose of HEV is estimated to be over $10^{5.5} \mathrm{HEV}$ RNA copies/g (Anses, 2009), we have confirmed the risk of transmission of HEV from pigs to humans through the consumption of food products containing raw pork liver.

\subsection{Phylogeny of HEV sequences from pork livers}

Of the 29 positive liver samples, 21 sequences were identified by RT-nested PCR (Genbank accession numbers MF065990-MF066010). Analysis of these sequences with reference HEV sequences, showed that all viral strains belonged to genotype 3 and subtypes 3c, 3e, 3f and $3 \mathrm{j}$ (Figure 2A). The presence of genotypes $3 \mathrm{c}, 3 \mathrm{e}$ and $3 \mathrm{f}$ has already been reported in France (Rose et al., 2011), but this is the first time that $3 \mathrm{j}$ has been detected in French pigs. The HEV-3j subtype (reference sequence AY115488) has only been described previously in North America (Canada) (Pei and Yoo, 2002). ). Sequences found within the same herd were very similar (>99\%), suggesting that only one main HEV strain circulates per herd. In a previous study, Bouquet et al. (2011) showed that the majority of the French swine HEV strains were of subtype $3 \mathrm{f}$, however in the present study 6 out 10 herds were infected by the subtype $3 \mathrm{c}$. This is in agreement with the recent description of an increase in human cases of HEV-3c type hepatitis E in France (Lhomme et al., 2015). Phylogenetic analysis was also performed with one sequence from each herd $(n=10)$ and the best hits in Genbank. Most of the HEV-3c sequences were highly similar (99\%) to French human cases and one Italian case where the patient had recently returned from France, and also to food products (99\%) (dried liver sausages) and to other swine sequences from the South of France (99\%) (Figure 2B). The HEV-3j sequence was relatively close to swine HEV from Canada, but not to that found in human cases or food products. The $2 \mathrm{HEV}-3 \mathrm{f}$ sequences were very similar to swine HEV from 
Spain. The swine HEV-3e sequence (FR-SHEV-LA-18-9-2011) was close to human cases of Hepatitis E from France and the UK. Identical HEV sequences in pig herds from France and England might explain this observation (Figure 2B). Several sequences were similar to human cases observed in 2013-2014, which is after the sampling period of the present study (2011), but it has been shown that HEV can be stable in space and time in animal populations (Jori et al., 2016). Thus, this suggests that the same HEV strains are still circulating in the contaminated herds sampled in 2011. This molecular study confirms the crucial role of the swine HEV reservoir in the persistent contamination of food products and human infections.

\subsection{HEV prevalence in pork muscles}

In our study, 1034 ham muscles collected at the slaughterhouse were examined for the presence of HEV RNA and were found to be negative (Table 1). These results are consistent with the findings of Leblanc et al. (2010), Berto et al. (2012) and Wilhelm et al. (2015) who were unable to detect HEV RNA in loins, ventral abdominal muscles and pork chops respectively. Three percent of 112 lingual muscles sampled at the slaughterhouse were found to be HEV RNA positive in the study by Di Bartolo et al. (2012). However, the authors suggested that the presence of the HEV genome was probably due to cross-contamination during slaughtering rather than real virus replication in muscle. Furthermore, the detection of HEV RNA in muscles has been previously described following an experimental assay of oneto-one exposure to infected pigs (Bouwknegt et al., 2009). However, the presence of HEV RNA on the surface of the muscle due to cross contamination with blood or within the tissue remains to be examined. Other studies identified the presence of HEV RNA in muscles following experimental intravenous contamination (Williams et al., 2001). In addition, the course of infection is different between contact-infection and intravenous inoculation, and 
they do not reflect the natural routes of transmission of HEV in animals (Bouwknegt et al., 2009; Kasorndorkbua et al., 2004).

Our results showed that positive livers were not associated with positive ham muscles even when the viral load in the liver exceeded $10^{6}$ copies/g. These findings are reassuring since, on average, 39425 tons of dried ham were produced per year in France between 2011 and 2015 (French federation of industrial pork butchers, caterers and meat processors (FICT), http://www.fict.fr/notre-industrie/chiffres-cles/).

\section{Conclusions}

This is the first time that a study analyzing over 1000 triplet samples of blood, muscle and liver has been conducted in French slaughterhouses. Under natural conditions of infection, ham muscles were not positive for HEV. Thus, our results showed a limited risk of contamination of ham muscles by HEV. In contrast, consumption of uncooked pork livers was confirmed to be a source of risk in human infection.

\section{Acknowledgments}

This work was supported by Inaporc and FranceAgrimer. We thank the slaughterhouses for their participation in the study.

\section{Conflicts of interest: none}

\section{References}

Adloch, C., Avellon, A., Baylis, S. A., Ciccaglione, A.R., Couturier, E., de Sousa, R., Epstein, J., Ethelberg, S., Faber, M., Feher, A., Ijaz, S., Lange, H., Mandakova, Z., Mellou, K., 
Mozalevskis, A., Rimhanen-Finne, R., Rizzi, V., Said, B., Sundqvist, L., Thornton, L., Tosti, M. E., van Pelt, W., Aspinall, E., Domanovic, D., Severi, E., Takkinen, J., Dalton, H. R. 2016. Hepatitis E virus: assessment of the epidemiological situation in humans in Europe, 2014/15. J. Clin. Virol. 82, 9-16.

Anses, French Agency for food, environmental and occupational health and safety. Avis de l'Agence française de sécurité sanitaire des aliments [cited 2009 Sept 23]. https://www.anses.fr/fr/system/files/MIC2009sa0146.pdf

Barnaud, E., Rogée, S., Garry, P., Rose, N., Pavio, N. 2012. Thermal inactivation of infectious hepatitis E virus in experimentally contaminated food. Appl. Environ. Microbiol. 78 (15): 5153.

Berto, A., Martelli, F., Grierson, S., Banks, M. 2012. Hepatitis E virus in pork food chain, United Kingdom, 2009-2010. Emerg. Infect. Dis. 18 (8), 1358-1360.

Blacksell, S.D., Myint, K.S., Khounsy, S., Phruaravanh, M., Mammen, M.P. Jr, Day, N.P., Newton, P.N. 2007. Prevalence of hepatitis E virus antibodies in pigs: implications for human infections in village-based subsistence pig farming in the Lao PDR. Trans. R Soc. Trop. Med. Hyg. 101(3), 305-307.

Bouquet, J., Tessé, S., Lunazzi, A., Eloit, M., Rose, N., Nicand, E., Pavio, N. 2011. Close similarity between sequences of hepatitis E virus recovered from humans and swine, France, 2008-2009. Emerg. Infect. Dis., 17(11), 2018-25. 
Bouwknegt, M., Lodder-Verschoor, F., van der Poel, W. H., Rutjes, S. A., de Roda Husman, A. M. 2007. Hepatitis E virus RNA in commercial porcine livers in the Netherlands. J. Food Prot. 70, 2889-95.

Bouwknegt, M., Rutjes, S., Reusken, C., Stockhofe-Zurwieden, N., Frankena, K., de Jong, M. C.M. de Roda Husman, A. M., van der Poel, W. H. M. 2009. The course of hepatitis E virus infection in pigs after contact-infection and intravenous inoculation. BMC V. Res. 5, 7.

Cooper K., Huang F.F., Batista L., Rayo C.D., Bezanilla J.C., Toth T.E., Meng X.J. 2005 Identification of genotype 3 hepatitis E virus (HEV) in serum and fecal samples from pigs in Thailand and Mexico, where genotype 1 and 2 HEV strains are prevalent in the respective human populations. J. Clin. Microbiol. 43, 1684-1688.

Costanzo, N., Sarno, E., Peretti, V., Ciambrone, L., Casalinuovo, F., Santoro, A. 2015. Serological and molecular investigation of swine hepatitis E virus in pigs raised in southern Italy. J. Food Prot. 78 (11), 2099-2102.

De Deus N., Casas M., Peralta B., Nofrarias M., Pina S., Martin M., Segales J. 2008. Hepatitis E virus infection dynamics and organic distribution in naturally infected pigs in a farrow-tofinish farm. Vet. Microbiol. 132, 19-28.

Di Bartolo, I., Diez-Valcarce, M., Vasickova, P., Kralik, P., Hernandez, M., Angeloni, G., Ostanello, F., Bouwknegt, M., Rodriguez-Lazaro, D., Pavlik, I., Ruggeri, F. M. 2012. Hepatitis E virus in pork production chain in Czech Republic, Italy, and Spain, 2010, Emerg. Infect. Dis. 18 (8), 1282-1289. 
Feagins, A. R., Opriessnig, T., Guenette, D. K., Halbur, P. G., Meng, X. J. 2007. Detection and characterization of infectious hepatitis E virus from commercial pig livers sold in local grocery stores in the USA. J. Gen. Virol. 88, 912-7.

Grierson, S., Heaney, J., Cheney, T., Morgan, D., Wyllie, S., Powell, L., Smith, D., Ijaz, S., Steinbach, F., Choudhury, B., Tedder, R.S. 2015. Prevalence of Hepatitis E virus infection in pigs at the time of slaughter, United Kingdom, 2013. Emerg. Infect. Dis. 21 (8), 1396-1401.

Ivanova, A., Tefanova, V., Reshetnjak, I., Kuznetsova, T., Geller, J., Lundkvist, A., Janson, M., Neare, K., Velström, K., Jokelainen, P., Lassen, B., Hütt, P., Saar, T., Viltrop, A., Golovljova, I. 2015. Hepatitis E virus in domestic pigs, wild boars, pig farm workers, and hunters in Estonia. Food Environ. Virol. 7 (4), 403-412.

Jiménez de Oya, N., de Blas, I., Blázquez, A. B., Martín-Acebes, M. A., Halaihel, N., Gironés, O., Saiz, J. C., Escribano-Romero, E. 2011. Widespread distribution of hepatitis E virus in Spanish pig herds. BMC Res. Notes, 4, 412.

Jori, F., Laval, M., Maestrini, O., Casabianca, F., Charrier, F., Pavio, N. 2016. Assessment of Domestic Pigs, Wild Boars and Feral Hybrid Pigs as Reservoirs of Hepatitis E Virus in Corsica, France. Viruses, 8 (8), 236.

Kasorndorkbua, C., Guenette, D. K., Huang, F. F., Thomas, P. J., Meng, X. J., \& Halbur, P. G. 2004. Routes of transmission of swine hepatitis E virus in pigs. J. Clin Microbiol, 42, 5047-5052. 
Leblanc, D., Poitras, E., Gagné, M.-J., Ward, P., Houde, A. 2010. Hepatitis E virus load in swine organs and tissues at slaughterhouse determined by real-time RT-PCR. Int. J. Food Microbiol, 139, 206-209.

IFIP, 2013. Le porc par les chiffres 2012-2013, La filière porcine en France dans l'UE et dans le monde. IFIP eds. Paris.

Lhomme, S., Abravanel, F., Dubois, M., Chapuy-Regaud, S., Sandres-Saune, K., Mansuy, J. M., Rostaing, L., Kamar, N., Izopet, J. 2015. Temporal evolution of the distribution of hepatitis E virus genotypes in Southwestern France. Infect. Genet. Evol. 35, 50-5.

Li, T.-C., Chijiwa, K., Sera, N., Ishibashi, T., Etoh, Y., Shinohara, Y., Kurata, Y., Ishida, M., Sakamoto, S., Takeda, N., Miyamura, T. 2005. Hepatitis E virus transmission from wild boar meat. Emerg. Infect. Dis. 11, 1958-1960.

Lu, L., Li, C., \& Hagedorn, C. H. 2006. Phylogenetic analysis of global hepatitis E virus sequences: genetic diversity, subtypes and zoonosis. Rev. Med. Virol. 16, 5-36.

Meng, X. J., Purcell, R. H., Halbur, P. G., Lehman, J. R., Webb, D. M., Tsareva, T. S., Haynes, J. S., Thacker, B. J., Emerson, S. U. 1997. A novel virus in swine is closely related to the human hepatitis E virus. Proc. Natl. Acad. Sci. USA, 94, 9860-9865.

Navaneethan, U., Al Mohajer, M., Shata, M.T. 2008. Hepatitis E and PregnancyUnderstanding the pathogenesis. Liver Int. 28 (9), 1190-1199. 
Pavio, N., Meng, X. J., Renou, C. 2010. Zoonotic hepatitis E: animal reservoirs and emerging risks. Vet. Res. 41, 46.

Pei,Y., Yoo,D. 2002. Genetic characterization and sequence heterogeneity of a Canadian isolate of Swine hepatitis E virus. J. Clin. Microbiol. 40 (11), 4021-4029.

Purcell, R.H., Emerson, S.U. 2008. Hepatitis E: an emerging awareness of an old disease. J. Hepatol. 48, 494-503.

Renou, C., Roque-Afonso, A. M., Pavio, N. 2014. Foodborne transmission of hepatitis E virus from raw pork liver sausage, France. Emerg. Infect. Dis. 20 (11), 1945-7.

Riveiro-Barciela, M., Minguez, B., Gironés, R., Rodriguez-Frias, F., Quer, J., Buti, M. 2015. Phylogenetic demonstration of hepatitis E infection transmitted by pork meat ingestion. J. Clin. Gastroenterol, 49 (2), 165-8.

Rose, N., Lunazzi, A., Dorenlor, V., Merbah, T., Eono, F., Eloit, M., Madec, F., Pavio, N. 2011. High prevalence of hepatitis E virus in French domestic pigs. Comp. Immunol. Microbiol. Infect. Dis. 34 (5), 419-27.

Seminati, C., Mateu, E., Peralta, B., de Deus, N., Martin, M. 2008. Distribution of hepatitis E virus infection and its prevalence in pigs on commercial farms in Spain. Vet J. 175, 130-132. 
Sergeant, E. S. G. 2017. Epitools epidemiological calculators. Ausvet Pty Ltd. Availabke at: http://epitools.ausvet.com.au.

Smith, D. B., Simmonds, P., Izopet, J., Oliveira-Filho, E. F., Ulrich, R. G., Johne, R., Koenig, M., Jameel, S., Harrison, T. J., Meng, X. J., Okamato, H., Van der Poel, W. H., \& Purdy, M. A. 2016. Proposed reference sequences for Hepatitis E virus subtypes. J. Gen. Virol. 97 (3), $537-42$.

Wacheck, S., Sarno, E., Märtlbauer, E., Zweifel, C., Stephan, R. 2012. Seroprevalence of Anti-Hepatitis E Virus and Anti-Salmonella Antibodies in Pigs at Slaughter in Switzerland. J. Food Prot. 75 (8), 1483-1485.

Wacheck, S., Werres, C., Mohn, U., Dorn, S., Soutschek, E., Fredriksson-Ahomaa, M., Märtlbauer, E. 2012b. Detection of IgM and IgG against hepatitis E virus in serum and meat juice samples from pigs at slaughter in Bavaria, Germany. Foodborne Pathog Dis. 9 (7), 655660.

Wenzel, J. J., Preiss, J., Schemmerer, M., Huber, B., Plentz, A., Jilg, W. 2011. Detection of hepatitis E virus (HEV) from porcine livers in southeastern Germany and high sequence homology to human HEV isolates. J. Clin. Virol. 52, 50-4.

Wilhelm, B. J., Leblanc, D., Avery, B., Pearl, D. L., Houde, A., Rajic, A., McEwen, S. A. 2015. Factors affecting detection of hepatitis E virus on Canadian retail pork chops and pork livers assayed using real-time RT-PCR. Zoonoses Public Health 63, 152-159. 
Williams, T. P., Kasorndorkbua, C., Halbur, P. G., Haqshenas, G., Guenette, D. K., Toth, T. E., Meng, X. J. 2001. Evidence of extrahepatic sites of replication of the hepatitis E virus in a swine model. J. Clin. Microbiol. 39, 3040-3046.

Yazaki, Y., Mizuo, H., Takahashi, M., Nishizawa, T., Sasaki, N., Gotanda, Y., Okamoto, H. 2003. Sporadic acute or fulminant hepatitis E in Hokkaido, Japan, may be food-borne, as suggested by the presence of hepatitis E virus in pig liver as food. J. Gen. Virol. 84 (9), 23512357. 
Table 1: Seroprevalence and HEV prevalence estimates at the individual pig-level (49 herds, 1034 triplet samples of blood, liver and muscle, France, 2011)

Figure 1: HEV quantification in livers (HEV RNA copies per gram of liver)

Figure 2: A) Phylogenetic tree of HEV sequences identified in pig samples. All $21 \mathrm{HEV}$ sequences (GenBank accession numbers MF065990 to MF066010) corresponding to the ORF-2 capsid nucleotides 6044-6334 of the reference sequence AF082843, were obtained by Sanger dideoxy sequencing (grey circle). They were aligned with references sequences (Smith et al 2016) using Muscle (MEGA6, www.megasoftware.net). Reference sequences for HEV-3 were: 3a AF082843, 3b AP003430, 3c FJ705359, 3e AB248521, 3f AB369687, 3g AF455784, 3h JQ013794, 3i FJ998008, 3j AY115488, AB290312, JQ953664, AB369689, AB290313, EU360977, KJ873911, EU723513. Countries of origin of the sequences used were CA: Canada; FR: France; GER: Germany; In JAVA: Indonesia; IT: Italy; JP: Japan; KY: Kyrgyzstan; MG: Mongolia; NL: the Netherlands; NW: Norway; SP: Spain; SW: Sweden; TH: Thailand; UK: the United Kingdom; the USA: United States of America. The origin of the host is indicated as followed: swine (S), wild boar (WB) and Human (Hu). B) Phylogenetic tree of HEV sequences from each pig herd and their best hits in Genbank. Ten HEV sequences (GenBank accession numbers MF065990, MF065992, MF065993, MF065994, MF065998, MF066001, MF066005, MF066006, MF066008 and MF066010) corresponding to the ORF-2 capsid nucleotides 6044-6334 of the reference sequence AF082843, were obtained by Sanger dideoxy sequencing (black circle). They were aligned with their 5 best hits in Genbank using Muscle (MEGA6, www.megasoftware.net). HEV sequences from humans: $\mathrm{Hu}$ (white diamond), food products: FIG: figatellu, SSF: dried liver sausage, SFF: fresh liver sausage (white triangle) or swine: S, are identified with their 
accession number and year of detection. Both trees were constructed using the neighbor-

joining method with a bootstrap of 1,000 replicates. Bootstrap values of $>70 \%$ are indicated on respective branches. Scale bar represents nucleotide substitutions per site. The two distinct clades and genotypes of HEV-3 are indicated by parentheses. 
Table 1

\begin{tabular}{lcccc}
\hline & Sample size & $\begin{array}{c}\text { positive } \\
\text { samples }\end{array}$ & $\begin{array}{c}\text { Prevalence } \\
\text { estimate (\%) }\end{array}$ & $\begin{array}{c}\text { 95\% Confidence } \\
\text { interval }\end{array}$ \\
\hline HEV serology & 1034 & 629 & 60 & $57.8-63.7$ \\
\hline $\begin{array}{l}\text { HEV RNA } \\
\text { (muscles) }\end{array}$ & 1034 & 0 & 0 & $0-0.003$ \\
\hline $\begin{array}{l}\text { HEV RNA } \\
\text { (liver) }\end{array}$ & 1034 & 29 & 2.8 & $1.9-3.9$ \\
\hline
\end{tabular}


Figure 1

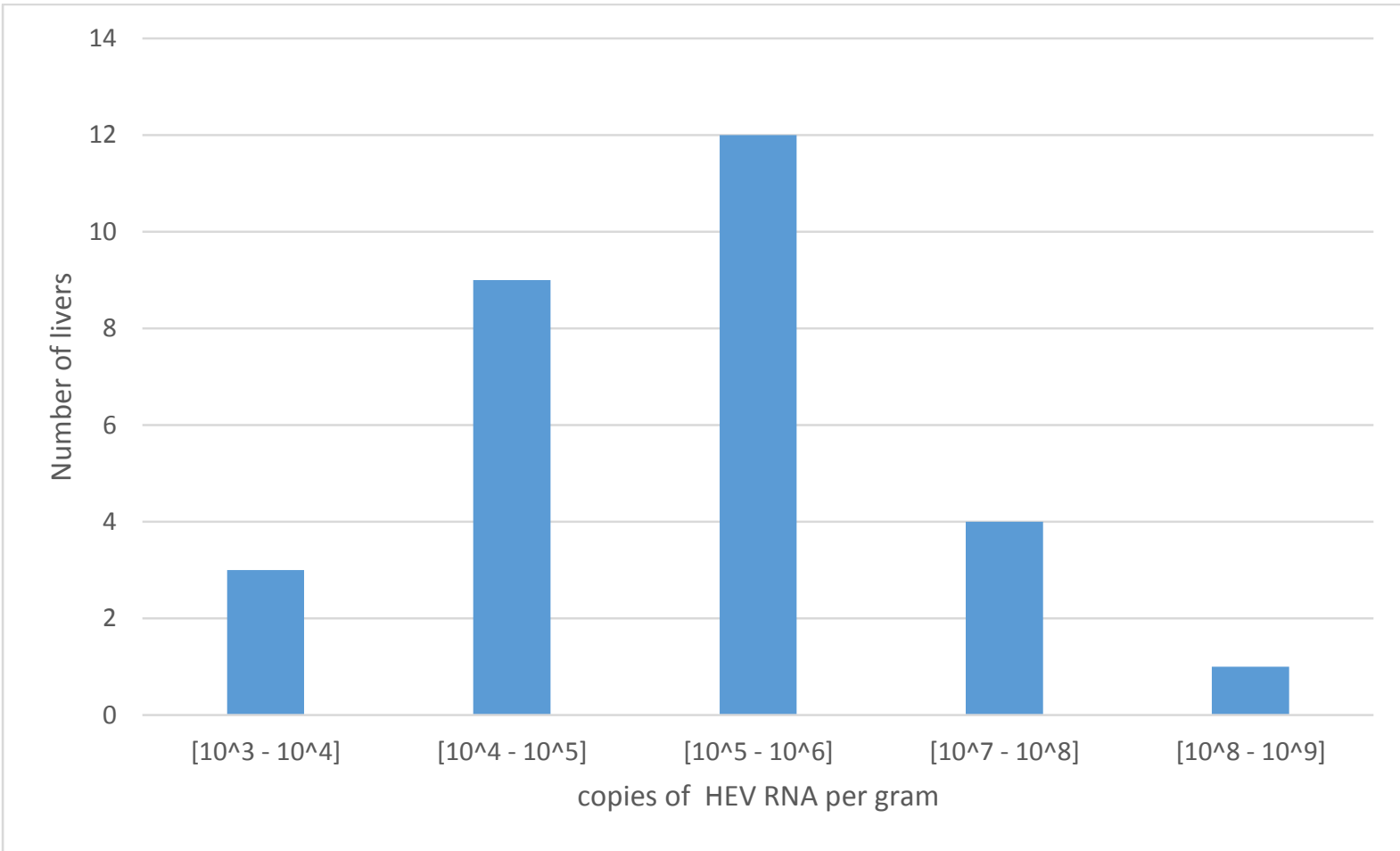




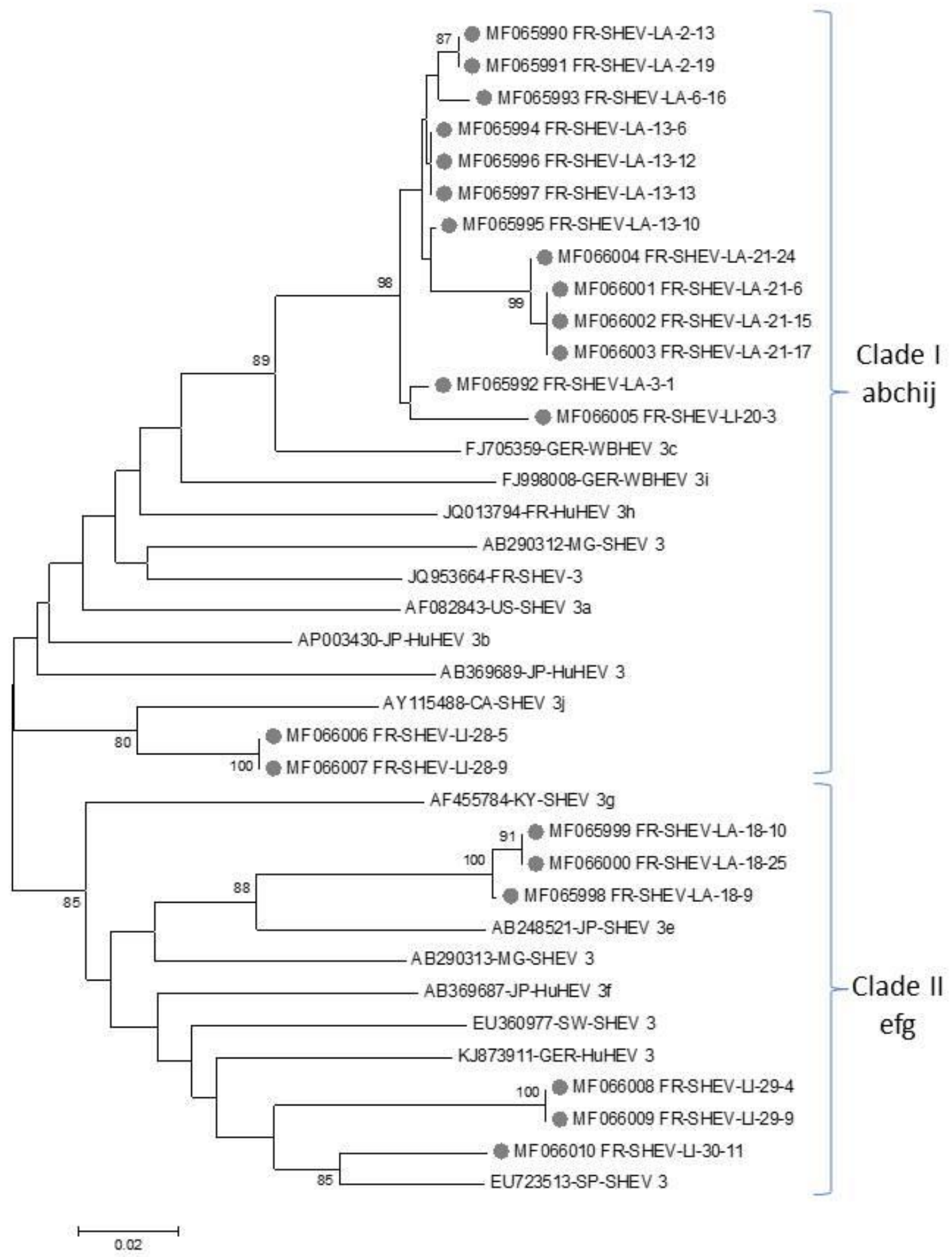

Figure 2A 


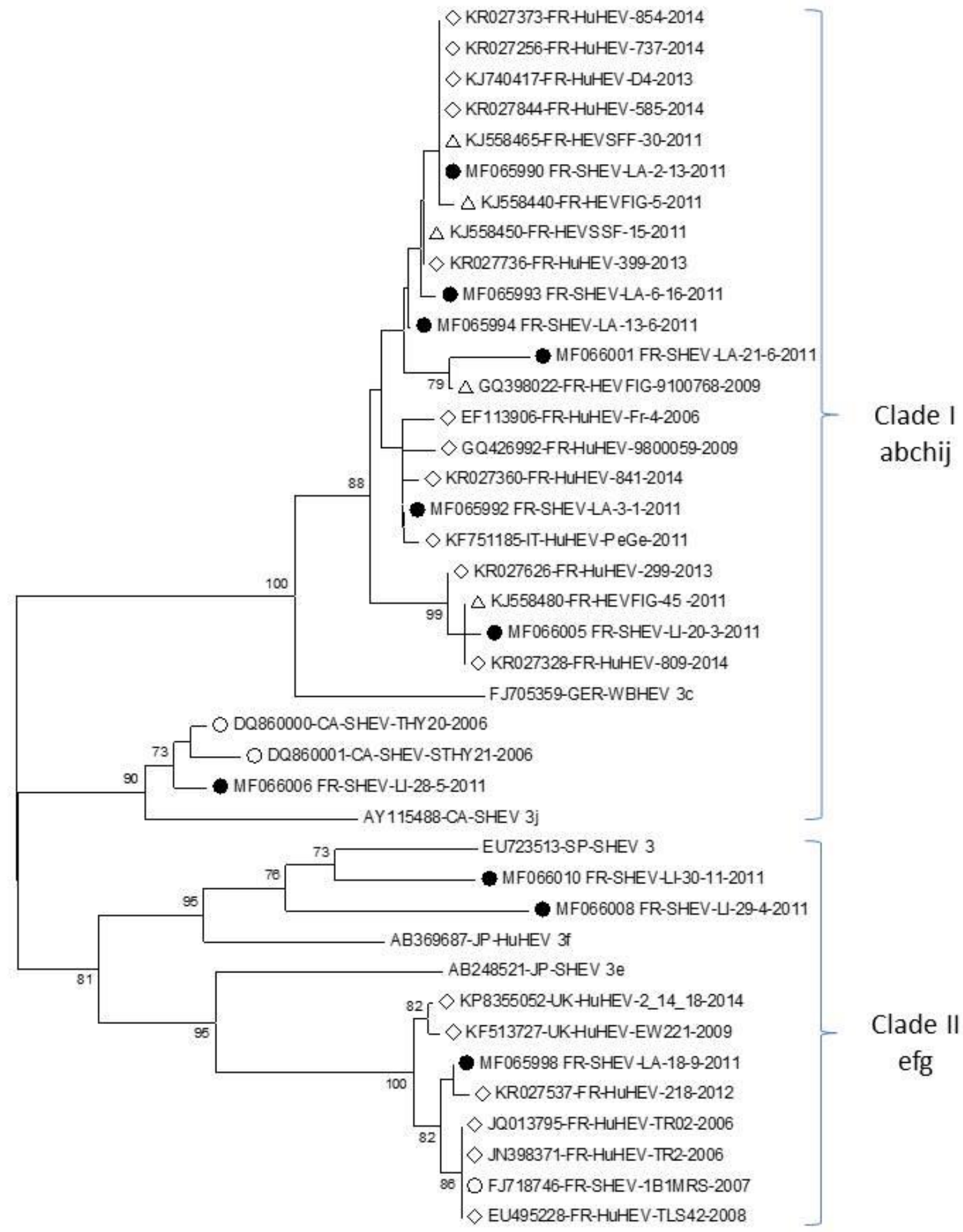

Figure 2B 